\title{
THE EFFECT OF FINANCIAL RATIO ANALYSIS ON THE FINANCIAL PERFORMANCE OF THE ISLAMIC PERSPECTIVE AT THE STATE ISLAMIC INSTITUTE (IAIN) PALANGKA RAYA FOR THE 2016-2018 PERIOD
}

\author{
Tiffianti Diannisa ${ }^{1}$, Abdul Qodir ${ }^{2}$ \\ Mahasiswa Prodi MES Pascasarjana IAIN Palangka Raya ${ }^{1}$, Dosen IAIN Palangka Raya ${ }^{2}$ \\ tiffianti@iain-palangkaraya.ac.id $^{1}$, abdul.qodir@iain-palangkaraya.ac.id ${ }^{2}$
}

\begin{abstract}
This study aims to analyze the financial statements at IAIN Palangka Raya for three periods, namely the 2016-2018 period. This analysis was conducted to determine the financial performance of higher education when viewed from the ROA. It is fitting that the performance of IAIN Palangka Raya is carried out in accordance with Islamic law. In addition to providing information on financial conditions, the results of financial ratio analysis can also be used as a basis for decision making, especially to improve the financial condition of IAIN Palangka Raya in the future. The financial statements will be analyzed using financial ratio analysis, including: liquidity ratios, debt to equity ratios and debt to income ratios. Comparisons are also made using Sharia provisions. The results obtained from this study are that in the 2016-2018 period the value of the IAIN Palangka Raya financial ratio analysis is still very good. When viewed from the results of the t test, the liquidity ratio, debt to equity ratio and debt to income ratio have a partially positive and significant effect on financial performance. Meanwhile, if viewed from the results of the $F$ test, the liquidity ratio, debt to equity ratio and debt to income ratio have a positive and significant effect simultaneously or together on financial performance in the IAIN Palangka Raya environment. So it can be said that IAIN Palangka Raya has performed well and is in accordance with sharia provisions.
\end{abstract}

Keywords: ratio, analysis

Kinerja keuangan Satuan Kerja (Satker) dapat dinilai dengan cara melakukan analisis laporan keuangan. Salah satu teknik analisis laporan keuangan yang populer dalam menilai kinerja keuangan adalah analisis rasio keuangan. Kinerja keuangan tercermin dari laporan keuangan seperti neraca, laporan operasional, laporan realisasi anggaran, dan laporan arus kas. Laporan keuangan perlu dianalisis untuk memberikan gambaran kinerja keuangan. Analisis laporan keuangan merupakan kegiatan untuk menginterpretasikan angka-angka dalam laporan keuangan dalam rangka menilai kinerja keuangan yang hasil analisis tersebut akan digunakan sebagai dasar pengambilan keputusan ekonomi, sosial, atau politik. Analisis laporan keuangan memerlukan teknik tertentu agar kegiatan 
analisis tersebut bermanfaat untuk pengambilan keputusan (Mahmudi, 2019:89). Analisis rasio keuangan yang digunakan antara lain: rasio likuiditas, rasio utang terhadap ekuitas, rasio utang terhadap pendapatan.

Institut Agama Islam Negeri (IAIN) Palangka Raya merupakan Perguruan Tinggi Keagamaan Islam Negeri yang berada di bawah tanggung jawab Kementerian Agama, jadi sudah selayaknya kinerja yang dilakukan sesuai dengan ketentuan-ketentuan atau syariat-syariat Islam. Islam adalah sebuah pedoman hidup dan berkehidupan yang dikeluarkan langsung oleh Allah SWT sebagai pencipta, pemilik, pemelihara dan penguasa tunggal alam semesta, agar manusia tunduk, patuh, dan pasrah kepada ketentuan-Nya untuk meraih derajat kehidupan lebih tinggi yaitu kedamaian, kesejahteraan, dan keselamatan baik di dunia maupun di akhirat. Terdapat tiga aspek yaitu akidah, syariah dan akhlak yang tidak dapat dipisahkan antara satu dengan lainnya (Nurhayati dan Wasilah, 2017:14). Ayat-ayat dan hadis tentang kinerja antara lain sebagai berikut:

1. Qs. Al-Nahl : 97

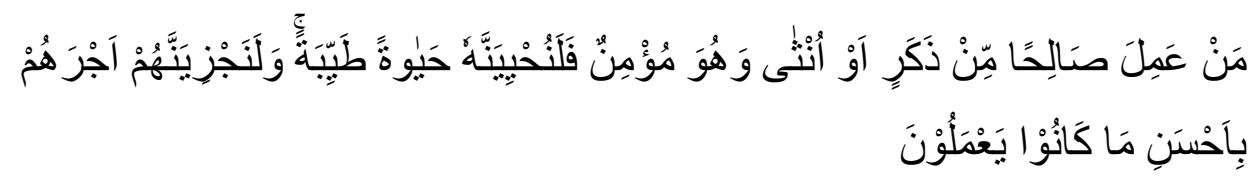

Terjemahnya:'Barangsiapa mengerjakan kebajikan, baik laki-laki maupun perempuan dalam keadaan beriman, maka pasti akan Kami berikan kepadanya kehidupan yang baik dan akan Kami beri balasan dengan pahala yang lebih baik dari apa yang telah mereka kerjakan."

Pada ayat ini Allah menerangkan beberapa kata kunci antara lain 'amila salihan, hayatan tayyibatan dan ajrahum bi ahsani ma kanu ya'malun. 'Amila salihan artinya beramal saleh, yaitu berbuat baik. Amal saleh dalam ayat ini mengandung dua dimensi: pertama, dimensi duniawi, yaitu amal saleh yang akan dibalas Allah dengan memberikan hayatan tayyibatan, yaitu kehidupan yang baik; kedua, amal saleh berdimensi ukhrawi yaitu amal saleh yang akan dibalas Allah dengan ajrahum bi-ahsani ma kanu ya 'malun, yaitu pahala yang lebih baik dari pada apa yang mereka kerjakan. Amal saleh dalam dimensi duniawi misalnya rajin bekerja, disiplin, datang tepat waktu, bekerja sesuai dengan petunjuk, peraturan dan ketentuan yang berlaku, tidak 
curang, tidak main-main tetapi bertanggung jawab (Lajnah Pentashihan Mushaf Al-Qur'an, 2009:4).

2. Qs. Al-Qasas: 77

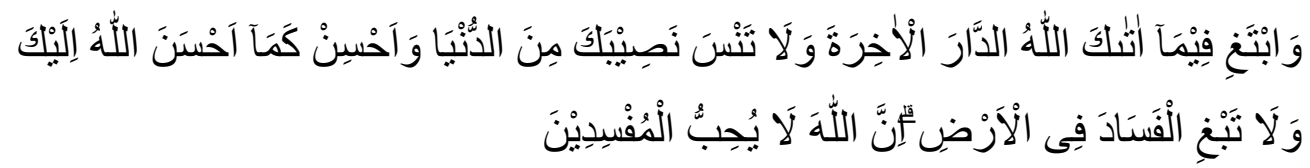

Terjemahnya:'Dan carilah (pahala) negeri akhirat dengan apa yang telah dianugerahkan Allah kepadamu, tetapi janganlah kamu lupakan bagianmu di dunia dan berbuat baiklah (kepada orang lain) sebagaimana Allah telah berbuat baik kepadamu, dan janganlah kamu berbuat kerusakan di bumi. Sungguh, Allah tidak menyukai orang yang berbuat kerusakan.”

Pada ayat ini Allah menerangkan bahwa kembali ke masalah hati; hati memang merupakan bagian yang sangat penting pada diri manusia, bahkan hati menunjukkan baik dan buruknya manusia. Sering kita dengar ucapan sehari-hari seperti, "Meskipun dia tidak pandai tetapi hatinya baik!". Atau ucapan yang lain, "Dia memang rajin tetapi hatinya kurang baik, tidak jujur." Hati sebagai kendali manusia untuk beriman kepada Allah dan Hari Akhir, dan iman itu baru sempurna jika mempunyai efek atau pengaruh pada lisan dan perbuatan manusia (Lajnah Pentashihan Mushaf Al-Qur'an, 2009:5-6).

3. Hadis Imam Bukhari

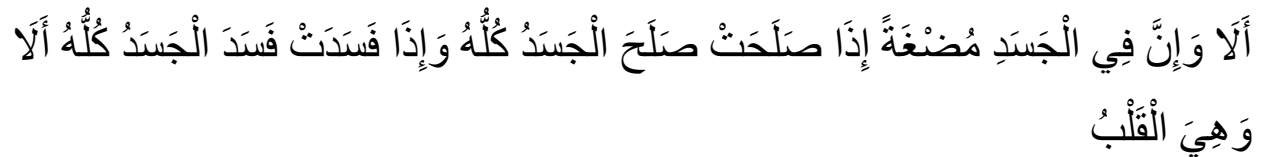

Artinya:" Ingatlah bahwa dalam tubuh manusia ada segumpal darah, jika baik gumpalan darah itu baik pulalah orang tersebut, dan jika gumpalan darah itu rusak maka rusak pulalah orang tersebut, gumpalan darah itu adalah hati. (HR. Bukhari No. 50)."

Hadis tersebut menjelaskan tentang Telah menceritakan kepada kami Abu Nu'aim Telah menceritakan kepada kami Zakaria dari 'Amir berkata; aku mendengar An Nu'man bin Basyir berkata; aku mendengar Rasulullah shallallahu 'alaihi wasallam bersabda: "Yang halal sudah jelas dan yang haram juga sudah jelas. Namun diantara keduanya ada perkara syubhat (samar) yang tidak diketahui oleh banyak orang. Maka barang siapa yang menjauhi diri dari yang syubhat berarti telah memelihara agamanya dan kehormatannya. Dan barang siapa yang sampai jatuh (mengerjakan) pada 
perkara-perkara syubhat, sungguh dia seperti seorang penggembala yang menggembalakan ternaknya di pinggir jurang yang dikhawatirkan akan jatuh ke dalamnya. Ketahuilah bahwa setiap raja memiliki batasan, dan ketahuilah bahwa batasan larangan Allah di bumi-Nya adalah apa-apa yang diharamkanNya. Dan ketahuilah pada setiap tubuh ada segumpal darah yang apabila baik maka baiklah tubuh tersebut dan apabila rusak maka rusaklah tubuh tersebut. Ketahuilah, ia adalah hati" (Lidwa Pusaka i-Sofware, Hadis No. 50).

Kementerian Agama Republik Indonesia memperoleh opini WTP selama tiga tahun berturut-turut yaitu tahun 2016-2018, dan Institut Agama Islam Negeri (IAIN) Palangka Raya merupakan bagian dari Kementerian Agama Republik Indonesia. Selama tahun 2016-2018 Perguruan Tinggi tersebut memperoleh penghargaan dalam hal pengelolaan dan pertanggungjawaban Anggaran Penerimaan dan Belanja Negara (APBN). Hal ini dapat dilihat pada tabel berikut:

Tabel 1. Laporan Realisasi APBN IAIN Palangka Raya Periode 2016-2018

\begin{tabular}{|c|l|c|c|c|}
\hline \multirow{2}{*}{ No. } & \multicolumn{1}{|c|}{ Uraian } & $\mathbf{2 0 1 6}$ & $\mathbf{2 0 1 7}$ & $\mathbf{2 0 1 8}$ \\
\cline { 3 - 5 } & Penerimaan & $\begin{array}{c}7.299 .215 .855 \\
(104,14 \%)\end{array}$ & $\begin{array}{c}9.671 .102 .779 \\
(110,96 \%)\end{array}$ & $\begin{array}{c}12.099 .958 .308 \\
(109,03 \%)\end{array}$ \\
\hline & $\begin{array}{l}\text { Negara Bukan } \\
\text { Pajak }\end{array}$ & $\begin{array}{c}68.796 .511 .194 \\
(96,48 \%)\end{array}$ & $\begin{array}{c}74.108 .402 .334 \\
(96,21 \%)\end{array}$ & $\begin{array}{c}51.735 .104 .751 \\
(98,35 \%)\end{array}$ \\
\hline
\end{tabular}

Sumber: Data diperoleh dari Bagian Perencanaan dan Keuangan IAIN Palangka Raya.

Selama tiga tahun Laporan Realisasi APBN IAIN Palangka Raya tergolong baik, baik dari segi Penerimaan Negara Bukan Pajak maupun dari Belanja Negara. Pada tahun 2018 belanja negara mengalami penurunan dibandingkan tahun 2016 dan 2017, hal ini disebabkan IAIN Palangka Raya tidak menerima dana pinjaman dan hibah atau dana Surat Berharga Syariah Negara (SBSN). Namun dari segi pengelolaan dan pertanggungjawaban laporan keuangan dapat dikatakan baik. Tidak ada kesenjangan didalam pelaksanaannya, akan tetapi masih belum ada kepastian antara pengaruh rasio likuiditas maupun rasio utang (rasio utang terhadap ekuitas dan rasio utang terhadap pendapatan) terhadap kinerja keuangan berbasis syariah pada IAIN Palangka Raya. Oleh sebab itu, 
penulis tertarik untuk melakukan penelitian dengan judul "Pengaruh Analisis Rasio Keuangan Terhadap Kinerja Keuangan Perspektif Syariah Pada Institut Agama Islam Negeri (IAIN) Palangka Raya Periode 2016-2018”.

\section{METODE}

Penelitian ini dikategorikan sebagai penelitian asosiatif kausal dengan menggunakan pendekatan kuantitatif. Dalam penelitian ini terdapat empat variabel yaitu tiga variabel independen (bebas) yaitu adalah rasio likuiditas $\left(\mathrm{X}_{1}\right)$, rasio utang terhadap ekuitas $\left(\mathrm{X}_{2}\right)$, rasio utang terhadap pendapatan $\left(\mathrm{X}_{3}\right)$, dan satu variabel dependen (terikat) yaitu kinerja keuangan (Y) yang dihitung dengan ROA. Analisis data bersifat statistik dengan tujuan untuk menguji hipotesis yang telah ditetapkan.

Populasi dalam penelitian ini adalah seluruh data time series (data deretan waktu) rasio likuiditas, rasio utang terhadap ekuitas, rasio utang terhadap pendapatan dan kinerja keuangan (ROA) selama periode 2016-2018. Agar dapat menggambarkan secara tepat variabel yang diteliti, maka peneliti mengambil semua populasi sebagai sampelnya. Oleh karena itu, pengambilan sampel dalam penelitian ini menggunakan metode sampling jenuh. Berdasarkan teknik pengambilan sampel tersebut, diperoleh jumlah sampel (n) dari data time series setiap bulan selama periode Januari 2016 - Desember 2018, yaitu sebanyak 36 sampel.

Teknik pengumpulan data yang digunakan dalam penelitian ini adalah dengan metode dokumentasi. Data tersebut diperoleh dari Bagian Keuangan dan BMN per bulan selama periode Januari 2016 - Desember 2018.

\section{HASIL}

Berdasarkan pada Laporan Keuangan IAIN Palangka Raya periode 20162018, telah dilakukan analisis rasio keuangan dengan menggunakan beberapa rasio, yaitu terlihat pada tabel di bawah ini:

Tabel 2. Analisis Rasio Keuangan Laporan Keuangan IAIN Palangka Raya Periode 2016-2018

\begin{tabular}{|c|c|c|c|c|c|}
\hline No. & Periode & $\begin{array}{c}\text { Rasio Lancar } \\
\text { (Likuiditas) }\end{array}$ & $\begin{array}{c}\text { Rasio Utang } \\
\text { terhadap } \\
\text { Ekuitas }\end{array}$ & $\begin{array}{c}\text { Rasio Utang } \\
\text { terhadap } \\
\text { Pendapatan }\end{array}$ & ROA \\
\hline 1 & Jan-16 & 0.987 & 0.009 & 0.534 & 0.009 \\
\hline
\end{tabular}




\begin{tabular}{|c|c|c|c|c|c|}
\hline 2 & Feb-16 & 0.794 & 0.012 & 0.380 & 0.000 \\
\hline 3 & Mar-16 & 0.933 & 0.013 & 0.434 & $(0.027)$ \\
\hline 4 & Apr-16 & 0.947 & 0.017 & 0.573 & $(0.058)$ \\
\hline 5 & May-16 & 0.897 & 0.010 & 0.349 & $(0.085)$ \\
\hline 6 & Jun-16 & 0.895 & 0.010 & 0.300 & $(0.141)$ \\
\hline 7 & Jul-16 & 0.882 & 0.011 & 0.304 & $(0.166)$ \\
\hline 8 & Aug-16 & 0.865 & 0.010 & 0.188 & $(0.160)$ \\
\hline 9 & Sep-16 & 0.869 & 0.009 & 0.145 & $(0.158)$ \\
\hline 10 & Oct-16 & 0.862 & 0.009 & 0.143 & $(0.179)$ \\
\hline 11 & Nov-16 & 0.853 & 0.009 & 0.138 & $(0.206)$ \\
\hline 12 & Dec-16 & 0.129 & 0.003 & 0.046 & $(0.251)$ \\
\hline 13 & Jan-17 & 1.059 & 0.004 & 0.216 & 0.013 \\
\hline 14 & Feb-17 & 1.152 & 0.008 & 0.263 & 0.003 \\
\hline 15 & Mar-17 & 1.153 & 0.008 & 0.266 & $(0.027)$ \\
\hline 16 & Apr-17 & 1.120 & 0.008 & 0.265 & $(0.051)$ \\
\hline 17 & May-17 & 1.102 & 0.008 & 0.263 & $(0.075)$ \\
\hline 18 & Jun-17 & 1.093 & 0.008 & 0.205 & $(0.112)$ \\
\hline 19 & Jul-17 & 1.080 & 0.008 & 0.138 & $(0.123)$ \\
\hline 20 & Aug-17 & 1.096 & 0.007 & 0.119 & $(0.136)$ \\
\hline 21 & Sep-17 & 1.069 & 0.007 & 0.109 & $(0.150)$ \\
\hline 22 & Oct-17 & 1.069 & 0.007 & 0.105 & $(0.176)$ \\
\hline 23 & Nov-17 & 1.056 & 0.007 & 0.102 & $(0.199)$ \\
\hline 24 & Dec-17 & 0.000 & 0.038 & 0.652 & $(0.269)$ \\
\hline 25 & Jan-18 & 1.000 & 0.006 & 0.710 & 0.040 \\
\hline 26 & Feb-18 & 1.137 & 0.006 & 0.240 & 0.044 \\
\hline 27 & Mar-18 & 1.129 & 0.006 & 0.226 & 0.026 \\
\hline 28 & Apr-18 & 1.095 & 0.006 & 0.219 & 0.002 \\
\hline 29 & May-18 & 1.081 & 0.006 & 0.197 & $(0.016)$ \\
\hline 30 & Jun-18 & 1.057 & 0.006 & 0.163 & $(0.054)$ \\
\hline 31 & Jul-18 & 1.059 & 0.006 & 0.115 & $(0.075)$ \\
\hline 32 & Aug-18 & 1.046 & 0.006 & 0.097 & $(0.085)$ \\
\hline 33 & Sep-18 & 1.036 & 0.006 & 0.091 & $(0.097)$ \\
\hline 34 & Oct-18 & 1.051 & 0.006 & 0.090 & $(0.132)$ \\
\hline 35 & Nov-18 & 1.034 & 0.006 & 0.087 & $(0.149)$ \\
\hline 36 & Dec-18 & 0.097 & 0.002 & 0.022 & $(0.213)$ \\
\hline
\end{tabular}

Sumber: Data diolah oleh peneliti

Jika dilihat dari tabel 2. maka dapat dikatakan bahwa nilai rasio likuiditas periode 2016-2018 rata-rata berada di bawah 1 ini menunjukkan bahwa IAIN Palangka Raya tergolong tidak sehat, akan tetapi masih dapat memenuhi kewajiban jangka pendek dengan menggunakan aktiva lancarnya. Nilai rasio utang terhadap ekuitas periode 2016-2018 dalam kondisi sangat baik karena nilai yang dihasilkan relatif sangat kecil, hal ini menunjukkan bahwa IAIN Palangka Raya tidak mengalami over-leveraged atau sangat terbebani utang. Nilai rasio utang terhadap pendapatan periode 2016-2018 dalam kondisi sangat baik, karena memiliki nilai relatif kecil. Hal ini berarti IAIN Palangka Raya memiliki kemampuan dalam membayar utangnya dengan menggunakan pendapatan pendidikan yang diterima. Nilai ROA 
rata-rata bernilai negative yang disebabkan oleh IAIN Palangka Raya bergerak dibidang usaha nirlaba dan menggunakan laporan keuangan pemerintah pusat dimana di dalam Laporan Operasionalnya memang diprediksi menghasilkan defisit. Penerapan anggaran defisit sejalan dengan pengganggaran berbasis kinerja, yaitu semakin besar beban yang dikeluarkan untuk mencari sumber penerimaan agar program dan kegiatan yang telah disetujui DPR dapat dilaksanakan pada tahun anggaran berjalan (Sukriy, 2013:1).

Selanjutnya dilakukan analisis Statistik Deskriptif menggunakan program Statistical Package For Social Sience 21.0 (SPSS 21.0) for windows.

Tabel 3. Deskripsi Statistik Masing-Masing Variabel

\begin{tabular}{|l|r|r|r|r|r|}
\hline & $\mathrm{N}$ & Minimum & Maximum & \multicolumn{1}{c|}{ Mean } & Std. Deviation \\
\hline Likuiditas & 36 & .000 & 1.153 & .93844 & .281616 \\
Utang thd ekuitas & 36 & .002 & .038 & .00856 & .005759 \\
Utang thd pendapatan & 36 & .022 & .710 & .23594 & .167086 \\
ROA & 36 & -.269 & .044 & -.09536 & .085337 \\
Valid N (listwise) & 36 & & & & \\
\hline
\end{tabular}

Sumber: Data diolah oleh peneliti

Tabel 4. Hasil Uji t

\begin{tabular}{|c|c|c|c|c|c|}
\hline \multirow[t]{2}{*}{ Model } & \multicolumn{2}{|c|}{$\begin{array}{l}\text { Unstandardized } \\
\text { Coefficients }\end{array}$} & $\begin{array}{l}\text { Standardized } \\
\text { Coefficients }\end{array}$ & \multirow[t]{2}{*}{$\mathrm{t}$} & \multirow[t]{2}{*}{ Sig. } \\
\hline & $\mathrm{B}$ & Std. Error & Beta & & \\
\hline (Constant) & -.249 & .039 & & -6.351 & .000 \\
\hline Likuiditas & .140 & .033 & .461 & 4.196 & .000 \\
\hline Utang thd ekuitas & -7.972 & 2.079 & -.538 & -3.836 & .001 \\
\hline $\begin{array}{l}\text { Utang thd } \\
\text { pendapatan }\end{array}$ & .385 & .065 & .754 & 5.905 & .000 \\
\hline
\end{tabular}

a. Dependent Variable: ROA

Sumber: Data diolah oleh peneliti

Uji statisitk t pada dasarnya menunjukkan seberapa jauh pengaruh satu variabel independen terhadap variabel dependen degan menganggap variabel independen lainnya konstan (Ghozali, 2017:23). Nilai t diperoleh pada bagian output koefisien regresi. Uji statistik $\mathrm{t}$ digunakan untuk pengujian hipotesis pengaruh variabel independen secara individu terhadap variabel dependen. Pengujian ini dilakukan dengan tingkat keyakinan $95 \%$.

Pada tabel di atas, dapat dilihat bahwa variabel rasio likuiditas memiliki nilai signifikansi sebesar 0,000 lebih kecil dari 0,05, rasio utang terhadap ekuitas memiliki nilai signifikansi sebesar 0,001 lebih kecil dari 0,05, rasio utang terhadap pendapatan memiliki nilai signifikansi sebesar 0,000 lebih kecil dari 
0,05. Sehingga dapat disimpulkan bahwa terdapat pengaruh positif dan signifikan antara rasio likuiditas (X1), rasio utang terhadap ekuitas (X2), dan rasio utang terhadap pendapatan (X3) terhadap kinerja keuangan secara parsial.

Tabel 5. Hasil Uji F

\begin{tabular}{|rl|r|r|r|r|r|}
\hline Model & & Sum of Squares & df & Mean Square & F & Sig. \\
\hline \multirow{3}{*}{1} & Regression & .178 & 3 & .059 & 24.724 & $.000^{\mathrm{b}}$ \\
& Residual & .077 & 32 & .002 & & \\
& Total & .255 & 35 & & & \\
\hline
\end{tabular}

a. Dependent Variable: ROA

b. Predictors: (Constant), Utang thd pendapatan, Likuiditas, Utang thd ekuitas

Sumber: Data diolah oleh peneliti

Uji statistik F pada dasarnya menunjukkan apakah semua variabel independen atau bebas yang dimasukkan dalam model mempunyai pengaruh secara bersama-sama terhadap variabel dependen atau terikat (Ghozali, 2017:22). Dari hasil uji $\mathrm{F}$ di atas, dapat disimpulkan bahwa terdapat pengaruh positif dan signifikan pada variabel bebas (independen) terhadap variabel terikat (dependen) secara simultan, karena tingkat signifikansi F sebesar 0,00 lebih kecil dari 0,05.

\section{PEMBAHASAN (Level II)}

\section{Analisis Rasio Keuangan}

Berdasarkan pada tabel 2. di atas, hasil analisis rasio keuangan IAIN Palangka Raya yaitu:

\section{a) Rasio Likuiditas}

Rasio likuiditas menujukan kemampuan pemerintah untuk memenuhi kewajiban jangka pendeknya. Walaupun pemerintah sudah menyusun anggaran kas, tetapi analisis likuiditas akan lebih bermanfaat bagi manajemen dibandingkan jika hanya mendasarkan pada anggaran kas saja. Nilai standar rasio lancar yang dianggap aman adalah 2:1. Namun angka tersebut tidaklah mutlak, sangat tergantung karakteristik aset lancar dan utang lancar. Tetapi nilai minimal yang masih bisa diterima adalah 1:1, jika kurang dari itu maka keuangan organisasi tidak lancar (Mahmudi, 2019:109). Analisis rasio likuiditas tertinggi terdapat pada bulan Maret 2017 sebesar 1,153 dan nilai terendah pada bulan Desember 2017 sebesar 0,000. Hal ini menunjukkan bahwa kemampuan 
tertinggi IAIN Palangka Raya dalam memenuhi kewajiban jangka pendeknya adalah pada bulan Maret 2017. Namun, jika dilihat secara terpisah, keuangan IAIN Palangka Raya dalam kondisi sehat. Karena nilai tersebut rata-rata berada di atas nilai minimal standar rasio yang masih bisa diterima yaitu 1:1. IAIN Palangka Raya memiliki utang kepada pihak ketiga/kewajiban jangka pendek pada neraca. Utang kepada pihak ketiga/kewajiban jangka pendek tersebut akan dibayarkan pada periode berikutnya. Hal ini disebabkan oleh kejadian-kejadian diluar rencana.

Rasio likuiditas dihitung dengan cara:

Rasio Lancar $=\underline{\text { Aktiva Lancar }}$ Utang Lancar

\section{b) Rasio Utang terhadap Ekuitas}

Rasio utang terhadap ekuitas atau total debt to equity ratio adalah untuk menunjukkan kemampuan modal sendiri (ekuitas) untuk memenuhi seluruh kewajibannya atau seluruh utangnya, baik kewajiban jangka pendek maupun jangka panjang. Rasio utang terhadap ekuitas yang tinggi mengindikasikan bahwa pemerintah mungkin seudah kelebihan utang (over-leveraged), dan harus segera mencari jalan untuk mengurangi utang. Semakin besar rasio ini menunjukkan risiko pemberian utang semakin besar (Mahmudi, 2019:111). Analisis rasio utang terhadap ekuitas tertinggi terdapat pada bulan Desember 2017 sebesar 0,038 dan nilai terendah pada bulan Desember 2018 sebesar 0,002. Dengan kata lain, keuangan IAIN Palangka Raya masih tergolong sangat baik, karena nilai rasio utang terhadap ekuitas tertinggi hanya 3,8\% tidak menunjukkan bahwa IAIN Palangka Raya sudah kelebihan utang (over-leveraged). Utang IAIN Palangka Raya masih sangat kecil jika dibandingkan dengan ekuitas yang dimiliki. Informasi ini juga dapat digunakan untuk mengetahui struktur pembiayaan IAIN Palangka Raya. Rasio utang terhadap ekuitas dihitung dengan cara: 
Rasio utang terhadap ekuitas $=\underline{\text { Total Utang }}$

Total Ekuitas

\section{c) Rasio Utang terhadap Pendapatan}

Rasio utang terhadap pendapatan digunakan untuk menggambarkan kapasitas pemerintah untuk membayar kembali utangnya dengan pendapatan yang diterima. Semakin rendah nilai rasio ini maka akan semakin baik (Mahmudi, 2019:124). Analisis rasio utang terhadap pendapatan tertinggi terdapat pada bulan Januari 2018 yaitu 0,710 dan nilai terendah pada bulan Desember 2018 sebesar 0,022. Dengan kata lain, keuangan IAIN Palangka Raya masih tergolong baik, karena nilai tertinggi sebesar $71 \%$. Hal ini disebabkan oleh adanya utang kepada pihak ketiga/kewajiban jangka pendek berupa belanja tunjangan kinerja untuk dosen yang masih belum bisa dibayarkan pada periode berjalan dikarenakan adanya aturan pembayaran tunjangan kinerja yang dikeluarkan secara tiba-tiba dan mengharuskan IAIN Palangka Raya untuk melakukan pencatatan kewajiban jangka pendek tersebut ke dalam neraca. Informasi tersebut dapat digunakan untuk mengetahui bahwa IAIN Palangka Raya mampu membayar utangnya dengan menggunakan pendapatan pendidikan.

Rasio utang terhadap pendapatan dihitung dengan cara:

Rasio utang terhadap pendapatan $=\underline{\text { Total Utang }}$

$$
\text { Pendapatan Pendidikan }
$$

\section{Kinerja Keuangan}

Kinerja keuangan disini dilihat dari kemampulabaan (profitabilitas), salah satu rasio profitabilitas yang sering digunakan adalah Return on Assets (ROA). ROA dapat digunakan sebagai alat analisis untuk mengukur kinerja dalam mendapatkan laba secara menyeluruh. Semakin besar nilai ROA maka semakin baik efektif dalam menggunakan aset (Agnes, 2005:19). Analisis ROA tertinggi terdapat pada bulan Februari 2018 yaitu 0,044 dan nilai terendah pada bulan Desember 2017 sebesar -0,269. Walaupun mengalami deficit bukan berarti keuangan IAIN Palangka Raya dikatakan buruk, hal ini disebabkan IAIN Palangka Raya merupakan instansi nirlaba, dan untuk 
melaksanakan setiap program memerlukan biaya yang cukup besar dan telah sesuai dengan perencanaan anggaran. Hal ini dibuktikan dengan diperolehnya penghargaan atas pengelolaan dan pertanggungjawaban APBN.

Untuk menghitung ROA dapat dilakukan dengan rumus sebagai berikut:

$\mathrm{ROA}=\frac{\text { Laba Bersih }+ \text { Bunga }}{\text { Total Aset rata-rata }}$

\section{Kinerja Keuangan Perspektif Syariah}

Mahsun (dalam Lucy Auditya, Husaini dan Lismawati, 2006:4) mengatakan bahwa kinerja itu sendiri adalah kemampuan kerja yang ditunjukkan dengan hasil kerja. Pemerintah dikatakan mempunyai kinerja baik apabila pemerintah tersebut mampu mengelola pemerintahan sehingga dapat memberikan kesejahteraan kepada masyarakatnya secara keseluruhan. Pengukuran kinerja instansi pemerintah memiliki kaitan erat dengan akuntabilitas dan transparansi. Untuk memantapkan mekanisme akuntabilitas, diperlukan manajemen kinerja yang baik. Pemahaman mengenai konsep kinerja organisasi publik dapat dilakukan dengan 2 (dua) pendekatan, yaitu melihat kinerja organisasi publik dari perspektif birokrasi itu sendiri, dan melihat kinerja organisasi publik dari perspektif kelompok sasaran atau pengguna jasa organisasi publik.

Para pekerja harus menjalankan tugasnya dengan penuh rasa tanggung jawab. Tanggung jawab kepada pemberi kerja dan tanggung jawab kepada Yang Maha Kuasa, Allah subhanahu wa ta'ala. Pertanggung jawaban itu sangat penting karena, seperti firman Allah, semua yang kita kerjakan harus dipertanggung jawabkan. Bahkan, pendengaran, penglihatan, pemikiran, apalagi pekerjaan, akan dimintai pertanggung jawabannya di hadapan Allah Rabbul-'Alamin. Yang penting adalah manusia bekerja dengan baik, optimal, dan sungguh-sungguh. Allah subhanahu wa ta'ala, sebagaiman firman-Nya dalam Q.S At-Taubah: 105: 


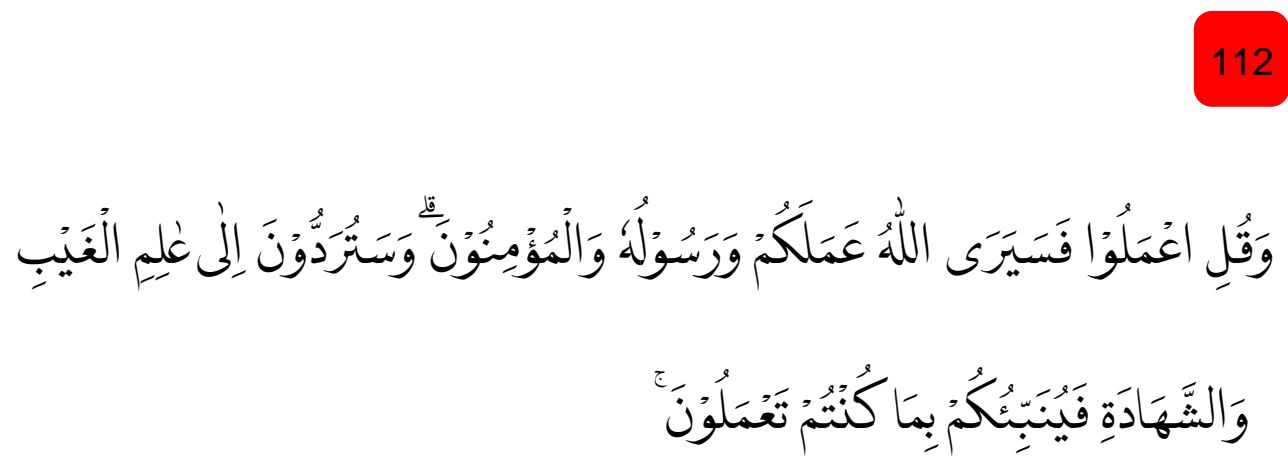

Terjemahnya: "Dan Katakanlah: "Bekerjalah kamu, Maka Allah dan rasulNya serta orang-orang mukmin akan melihat pekerjaanmu itu, dan kamu akan dikembalikan kepada (Allah) yang mengetahui akan yang ghaib dan yang nyata, lalu diberitakan-Nya kepada kamu apa yang Telah kamu kerjakan.”

Dalam tafsir al-Muntakhab dijelaskan bahwa manusia diperintah untuk bekerja, dan tidak boleh melakukan reduksi (pengurangan) terhadap pekerjaannya, begitu juga dalam menunaikan kewajiban, karena Allah subhanahu wa ta'ala pasti mengetahui semuanya. Selain pekerja harus bekerja maksimal memenuhi standar kerja yang sama atau melebihi tuntutan pekerjaannya, ia juga harus memiliki kejujuran dan dapat bekerja secara professional (Lajnah Pentashihan Mushaf Al-Qur'an, 2009:169-170).

Ayat di atas mengingatkan kita agar tidak bekerja asal-asalan, sebab Allah menyaksikan segala pekerjaan kita, sehingga bila ingin mendapatkan keridaan-Nya maka persembahkanlah pekerjaan yang berkualitas. Anjuran atau perintah untuk bekerja secara profesional dan berkualitas berarti juga anjuran atau perintah untuk mewujudkan segala sesuatu yang mengantarkan pada kualitas dan profesionalitas, antara lain melalui pendidikan dan pelatihan. Dalam kaidah fikih, perintah untuk melakukan sesuatu juga merupakan perintah untuk mewujudkan segala sesuatu yang mengantarkan kepada terwujudnya perintah tersebut (al-'amru bisy-syai'i amrun biwasa'ilihi) (Lajnah Pentashihan Mushaf Al-Qur'an, 2009:381).

Peningkatan kompetensi kerja akan menghasilkan pekerjaan yang berkualitas. Islam menganjurkan agar setiap pekerja melakukan tugasnya secara profesional dan berkualitas (Lajnah Pentashihan Mushaf Al-Qur'an, 2009:380). 
Selain itu, Allah subhanahu wa ta'ala tidak menyukai orang yang hidup berlebihan atau boros, sebagaiman firman-Nya dalam Q.S Al-Furqan: 67:

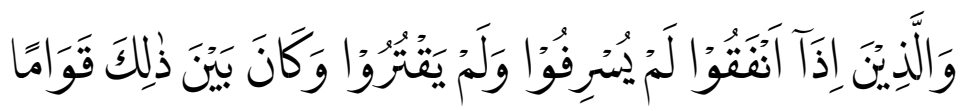

Terjemahnya: "Dan orang-orang yang apabila membelanjakan (harta), mereka tidak berlebihan, dan tidak (pula) kikir, dan adalah (pembelanjaan itu) di tengah-tengah antara yang demikian.”

Melalui ajaran ini Allah dan Rasul-Nya mengingatkan manusia untuk dapat memelihara hartanya, tidak memboroskan hingga habis, tetapi di saat yang sama tidak menahannya sama sekali sehingga mengorbankan kepentingan pribadi, keluarga, atau siapa pun yang butuh pertolongan. Berkenaan dengan ayat ini, menurut al-Qardhawi, sebagian manusia ada yang menumpuk harta, lalu dia kikir terhadap diri sendiri dan keluarganya, dalam arti harta benda ada di tangannya tapi dia tidak mau menggunakannya (Lajnah Pentashihan Mushaf Al-Qur'an, 2009:73-74).

Media yang dapat digunakan dalam mengukur kondisi kinerja keuangan satuan kerja tersebut adalah laporan keuangan yang terdiri dari Laporan Realisasi Anggaran, Laporan Operasional, Laporan Perubahan Ekuitas, Neraca, dan Catatan atas Laporan Keuangan. Catatan atas Laporan Keuangan mencakup informasi tentang kebijakan akuntansi yang dipergunakan oleh entitas pelaporan dan informasi lain yang diharuskan dan dianjurkan untuk diungkapkan di dalam Standar Akuntansi Pemerintahan (SAP) serta ungkapan-ungkapan yang diperlukan untuk menghasilkan penyajian laporan keuangan secara wajar.

\section{Kinerja Keuangan di IAIN Palangka Raya}

Berdasarkan hasil pengamatan peneliti selama melakukan penelitian, kinerja keuangan IAIN Palangka Raya dapat dikatakan baik. Hal ini dibuktikan oleh adanya beberapa piagam penghargaan terkait pengelolaan dan pertanggung jawaban APBN pada tahun 2016 dan 2017. Selain itu, IAIN Palangka Raya memperoleh nilai akreditasi B pada tahun 2018. Dan jika 
dilihat dari division of labour (pembagian kerja) sudah sesuai dengan keahlian masing-masing. Keadaan ini sesuai dengan Q.S At-Taubah: 105.

\section{Laporan Keuangan}

Laporan Keuangan adalah bentuk pertanggungjawaban pemerintah atas pelaksanaan Anggaran Penerimaan dan Belanja Negara (APBN) berupa laporan realisasi anggaran, neraca, laporan arus kas, laporan operasional, laporan perubahan ekuitas, laporan perubahan Saldo Anggaran Lebih, dan CaLK (PMK RI No. 215/PMK.05/2016).

Laporan Keuangan disajikan kepada pemangku kepentingan bukan untuk mempersulit dan membingungkan pembacanya tetapi justru untuk membantu mereka dalam membuat keputusan politik, sosial dan ekonomi sehingga keputusan yang diambil bisa lebih berkualitas (Mahmudi, 2019:1).

Laporan keuangan yang dibuat dan disusun bukan hanya sebagai hasil dari pencatatan dan pelaporan saja, tetapi juga sebagai alat untuk menjalankan nilai-nilai Islam sesuai ketentuan syariah. Hal ini tertuang dalam Q.S AlBaqarah : 282 (Husein, 2001:63-64).

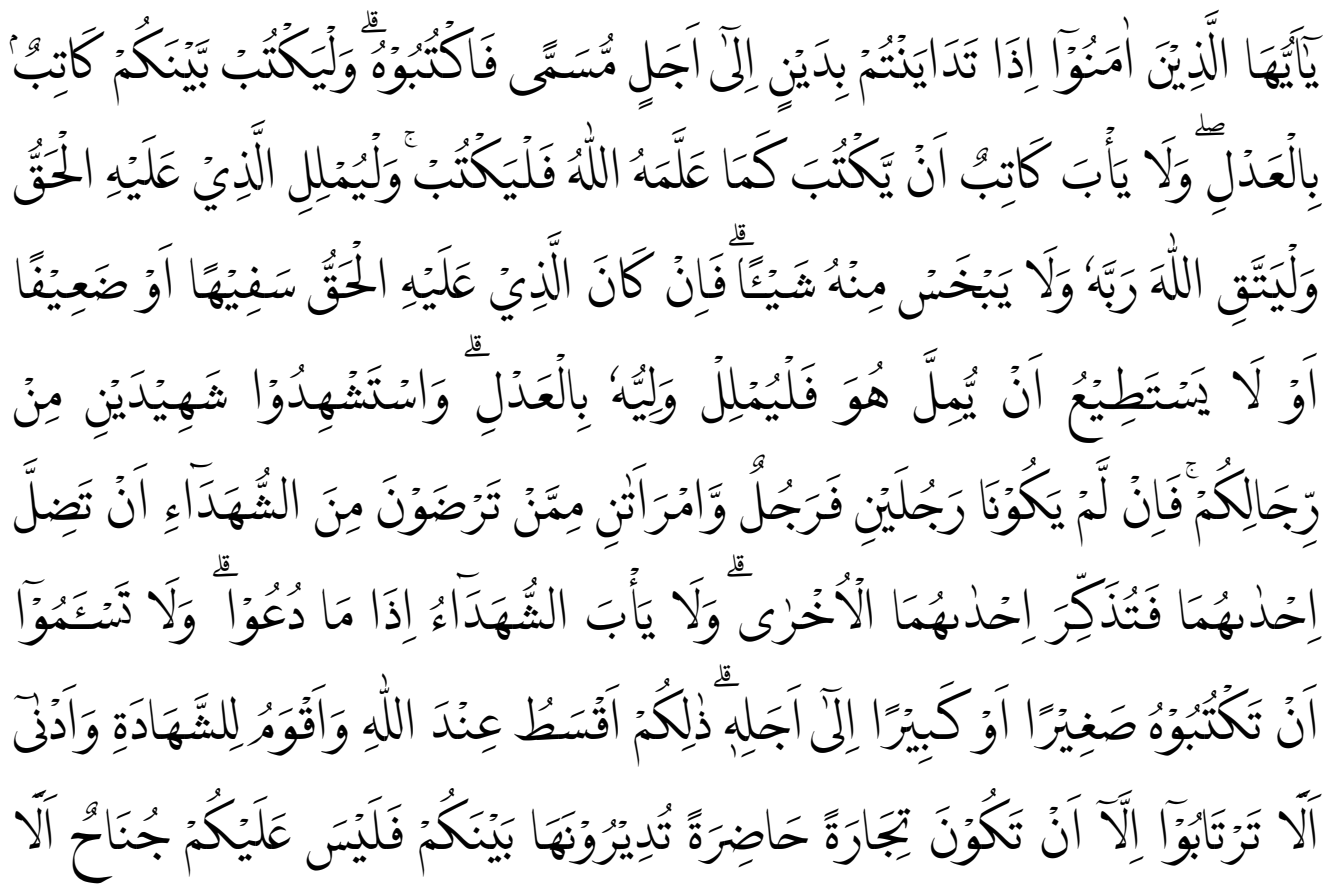




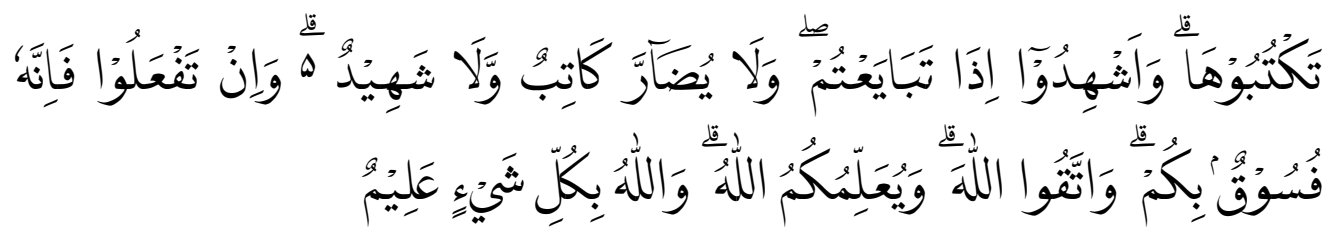

Terjemahnya: "Wahai orang-orang yang beriman! Apabila kamu melakukan utang piutang untuk waktu yang ditentukan, hendaklah kamu menuliskannya. Dan hendaklah seorang penulis di antara kamu menuliskannya dengan benar. Janganlah penulis menolak untuk menuliskannya sebagaimana Allah telah mengajarkan kepadanya, maka hendaklah dia menuliskan. Dan hendaklah orang yang berutang itu mendiktekan, dan hendaklah dia bertakwa kepada Allah, Tuhannya, dan janganlah dia mengurangi sedikit pun daripadanya. Jika yang berutang itu orang yang kurang akalnya atau lemah (keadaannya), atau tidak mampu mendiktekan sendiri, maka hendaklah walinya mendiktekannya dengan benar. Dan persaksikanlah dengan dua orang saksi laki-laki di antara kamu. Jika tidak ada (saksi) dua orang laki-laki, maka (boleh) seorang lakilaki dan dua orang perempuan di antara orang-orang yang kamu sukai dari para saksi (yang ada), agar jika yang seorang lupa, maka yang seorang lagi mengingatkannya. Dan janganlah saksi-saksi itu menolak apabila dipanggil. Dan janganlah kamu bosan menuliskannya, untuk batas waktunya baik (utang itu) kecil maupun besar. Yang demikian itu, lebih adil di sisi Allah, lebih dapat menguatkan kesaksian, dan lebih mendekatkan kamu kepada ketidakraguan, kecuali jika hal itu merupakan perdagangan tunai yang kamu jalankan di antara kamu, maka tidak ada dosa bagi kamu jika kamu tidak menuliskannya. Dan ambillah saksi apabila kamu berjual beli, dan janganlah penulis dipersulit dan begitu juga saksi. Jika kamu lakukan (yang demikian), maka sungguh, hal itu suatu kefasikan pada kamu. Dan bertakwalah kepada Allah, Allah memberikan pengajaran kepadamu, dan Allah Maha Mengetahui segala sesuatu."

Di sini, Allah juga melarang kita dari meninggalkan pencatatan transaksitransaksi, baik yang kecil maupun yang besar. Ini menunjukkan bahwa tidak menuliskan transaksi-transaksi itu (kecil atau besar) hukumnya adalah dilarang.

Penyusunan laporan keuangan didasarkan pada sifat laporan keuangan, dalam praktiknya sifat laporan keuangan dibuat:

a) Bersifat Historis

Bersifat historis artinya bahwa laporan keuangan dibuat dan disusun dari data masa lalu atau masa yang sudah lewat dari masa sekarang.

b) Bersifat Menyeluruh 
Bersifat menyeluruh maksudnya laporan keuangan dibuat selengkap mungkin. Artinya laporan keuangan disusun sesuai dengan standar yang telah ditetapkan (Kasmir, 2018:11-12).

\section{Laporan Keuangan IAIN Palangka Raya}

Laporan keuangan IAIN Palangka Raya dibuat dengan menggunakan basis akrual. Hal ini dibuktikan dengan adanya pencatatan terhadap belanja gaji pegawai yang terhutang pada tahun berjalan, selain itu terdapat pencatatan penerimaan pendapatan sewa di terima dimuka pada neraca, dan apabila tidak memungkinkan untuk melakukan pencatatan pada neraca maka pencatatan dilakukan dalam bentuk Catatan atas Laporan Keuangan (CaLK) yang merupakan bagian dari pelaporan keuangan. Setiap bulan dilakukan rekonsiliasi data keuangan dengan Kantor Pelayanan Perbendaharaan Negara (KPPN) Palangka Raya. Keadaan ini telah sesuai dengan Q.S Al-Baqarah: 282. 
7. Pengaruh rasio likuiditas $\left(\mathbf{X}_{1}\right)$, rasio utang terhadap ekuitas $\left(\mathbf{X}_{2}\right)$, rasio utang terhadap pendapatan $\left(\mathrm{X}_{3}\right)$ terhadap kinerja keuangan (Y)

Berdasarkan hasil uji t pada tabel 4. di atas dapat disimpulkan bahwa variabel rasio likuiditas, rasio utang terhadap ekuitas, dan rasio utang terhadap pendapatan secara parsial memiliki pengaruh positif dan signifikan terhadap kinerja keuangan.

Sedangkan hasil uji F pada tabel 5. di atas, dapat disimpulkan bahwa rasio likuiditas $\left(\mathrm{X}_{1}\right)$, rasio utang terhadap ekuitas $\left(\mathrm{X}_{2}\right)$, dan rasio utang terhadap pendapatan $\left(\mathrm{X}_{3}\right)$ secara simultan atau bersama-sama berpengaruh positif dan signifikan terhadap kinerja keuangan (Y).

Dari kedua penjelasan tersebut dapat disimpulkan bahwa secara parsial (sendiri-sendiri) variabel independen (bebas) memiliki pengaruh secara positif dan signifikan terhadap variabel dependen (terikat). Dan secara simultan (bersama-sama) variabel independen (bebas) memiliki pengaruh secara positif dan signifikan terhadap variabel independen (terikat).

Berdasarkan Tabel 2. di atas, dapat disimpulkan bahwa pada periode 2016-2018 nilai analisis rasio keuangan IAIN Palangka Raya masih tergolong sangat baik dan sehat. Sehingga dapat dikatakan IAIN Palangka Raya telah melakukan kinerja keuangan dengan baik dan sesuai dengan syariah. Hal ini dapat dilihat dari segi penyusunan laporan keuangan yang menggunakan basis akrual seperti yang tertuang dalam Q.S Al-Baqarah: 282 dan kinerja pendapatan yang memiliki nilai positif sesuai dengan Q.S At-Taubah: 105.

Jika dilihat dari proses penyusunan, pengelolaan dan pertanggung jawaban laporan keuangan, IAIN Palangka Raya secara tidak langsung sudah menerapkan prinsip-prinsip syariah. Namun, akan lebih baik lagi jika IAIN Palangka Raya membuat laporan dana zakat salah satunya zakat penghasilan yang diambil dari sebagian gaji seluruh pegawai dan kemudian disalurkan kepada masyarakat yang membutuhkan, tentunya pengelolaannya disesuaikan dengan aturan-aturan yang ada dalam PSAK Nomor 101. 


\section{KESIMPULAN}

Dari hasil penelitian di atas, maka dapat diambil kesimpulan bahwa pada periode 2016-2018 nilai analisis rasio keuangan IAIN Palangka Raya masih tergolong sangat baik. Jika dilihat dari hasil di atas, rasio likuiditas, rasio utang terhadap ekuitas, rasio utang terhadap pendapatan baik secara parsial maupun secara simultan atau bersama-sama berpengaruh positif dan signifikan terhadap kinerja keuangan di lingkungan IAIN Palangka Raya. Selain itu, IAIN Palangka Raya dapat dikatakan telah melakukan kinerja keuangan berbasis syariah dengan baik.

Dari hasil penelitian ini, dapat diambil kesimpulan sebagai berikut:

1. Korelasi atau hubungan antara variabel dependen (ROA) terhadap variabel independennya secara simultan memiliki hubungan yang erat, dengan nilai sebesar $83,6 \%$, sehingga penelitian ini dapat dikatakan baik.

2. Jika dilihat dari hasil $\mathrm{R}$ square dapat dikatakan bahwa secara simultan antara variabel independen berpengaruh terhadap variabel dependen sebesar 69,9\% dan sisanya dipengaruhi oleh variabel lain diluar penelitian.

3. Rasio likuiditas, rasio utang terhadap ekuitas (Debt to Equity Ratio), rasio utang terhadap pendapatan (Debt to Income Ratio) baik secara parsial maupun secara simultan memiliki pengaruh positif dan signifikan terhadap kinerja keuangan IAIN Palangka Raya jika dilihat dari ROA.

4. Berdasarkan hasil penelitian di atas, IAIN Palangka Raya dapat dikatakan telah melakukan kinerja keuangan sesuai perspektif syariah. 


\section{DAFTAR PUSTAKA}

Abdullah, Syukriy. 2013. Defisit/Surplus dan SILPA dalam Anggaran Daerah Apakah Saling Berhubungan?, https://syukriy.wordpress.com (on line 7 September 2020).

Auditya Lucy, Husaini dan Lismawati. 2013. “Analisis Pengaruh Akuntabilitas Dan Transparansi Pengelolaan Keuangan Daerah Terhadap Kinerja Pemerintah Daerah”. Jurnal Fairness Volume 3 Nomor 1.

Ghozali, Imam. 2017. Ekonometrika. Semarang: Badan Penerbit Universitas Diponegoro.

Kasmir. 2018. Analisis Laporan Keuangan. Depok: Rajawali Pers.

Lajnah Pentashihan Mushaf Al-Qur'an. 2009. Tafsir Al-Qur'an Tematik: Etos Kerja. Jakarta: Badan Litbang Dan Diklat Departemen Agama RI.

------. 2009. Tafsir Al-Qur'an Tematik: Pembangunan Ekonomi Umat. Jakarta: Badan Litbang Dan Diklat Departemen Agama RI.

------. 2016. Qur'an Kemenag In Microsoft Word Versi 2010, 2013, 2016, 2019 dan Net Framework Versi 4.

Lidwa Pusaka i-Sofware. Kitab 9 Imam Hadist.

Mahmudi. 2019. Analisis Laporan Keuangan Pemerintah Daerah. Yogyakarta: Unit Penerbit dan Percetakan Sekolah Tinggi Ilmu Manajemen YKPN.

Nurhayati, Siti dan Wasilah. 2017. Akuntansi Syariah di Indonesia Edisi 4. Jakarta: Salemba Empat.

Peraturan Menteri Keuangan Republik Indonesia Nomor 215 /PMK.05/2016 Tentang Perubahan Atas Peraturan Menteri Keuangan Nomor 
213/PMK.05/2013 Tentang Sistem Akuntansi Dan Pelaporan Keuangan Pemerintah Pusat.

Sawir, Agnes. 2005. Analisis Kinerja Keuangan dan Perencanaan Keuangan Perusahaan. Jakarta: PT Gramedia Pustaka Utama.

Syahatah, Husein. 2001. Pokok-Pokok Pikiran Akuntansi Islam. Jakarta: Akbar Media Eka Saran. 